\title{
THE IMPACT OF SOCIAL EXPENDITURE ON PUBLIC DEBT IN THE CZECH REPUBLIC AND SLOVAKIA
}

\author{
Manuela Raisová, L'udmila Pavliková, Jozefína Semančíková
}

\section{Introduction}

Fiscal policy setting regarding a long-term sustainability of public finance represents a serious problem not only in the EU member countries. The severity of the problem has been magnified by the debt and economic crisis within the previous years. The problem mentioned is associated with the development of private and public consumption, changes in investment, development of financial markets and the negative impact of demographic development in Europe as well. Moreover, it is obvious that pensions will continue to increase in the EU member countries. This trend is confirmed by the previous development since 2004 and the forecasts of empirical studies, e.g. Ellison (2012), EACG (2012), EC (2012a), EC (2012b). The aim of the European leaders should be reflected in finding a quick, sustainable solution to the overall situation that would be beneficial for the common market and the individual markets too. The sustainable solution does not necessarily mean zero level of public debt or adherence to the golden rule each financial year. As mentioned in the study of Cecchetti, Mohanty and Zampolli (2011), although debt at moderate levels improves welfare and enhances growth, high levels can be damaging. However, the problem is society and its habits. People, governments, firms are used to have access to finance. Indeed, such countries without finance and debt become poor and stay poor. In the case they have a possibility of borrowing and saving the money, individuals are able to consume even without current income. Considering a debt, businesses can invest, even though their sales would otherwise not allow it. Therefore, when they are able to borrow, fiscal authorities may play their role in stabilising the macroeconomy. However, history has taught us that borrowing may result in vulnerabilities. Particularly, when debt ratios rise beyond a certain level, financial crises become both more likely and more severe (Reinhart \& Rogoff, 2009).

In our investigations, we focused primarily on the public sector. We did not take into account the behavior of households and firms, but we focused only on government behaviour. Especially, we examine the influence of public expenditure on public debt using a data set on the level of public expenditure in the Czech Republic and Slovakia from 1993 to 2015. For that reason, the basic hypotheses are formulated as follows:

$H_{0}$ : Public expenditure is more significantly correlated with the changes in public debt than other analysed variables.

$H_{1}$ : Public expenditure is less significantly correlated with the changes in public debt than other analysed variables.

It should be noted that one of the problems associated with the growth of public expenditure is the growth of social expenditure. For that reason, such a system of an economy should meet the criteria for the EU optimal functioning regardless the impact of public expenditure sensitive to the population aging. Therefore, the particular importance should be oriented to a regular monitoring of this expenditure in the long term mainly due to persistent increases in spending on pensions. Based on the conclusions of various empirical studies (Jaime-Castillo, Marques-Perales, \& AlvarezGalvez, 2016; Soltes \& Gavurova, 2014) and the reasons above, we decided to test the hypothesis on social expenditure being more significantly correlated with the changes in public debt in selected countries than the other variables.

The hypotheses are formulated as follows:

$H_{0}$ : Social expenditure is more significantly correlated with the changes in public debt than other analysed variables. 
$H_{1}$ : Social expenditure is less significantly correlated with the changes in public debt than other analysed variables.

In order to test the hypothesis, we apply several regression linear models. This approach would enable us to identify the relationship between the changes in a variable and the changes in public debt. The aim is to test the assumption that public expenditure represents a statistically serious problem related to the public debt development in the Czech Republic and Slovakia as well in the long term. Particularly, we focus on the category of social expenditure as this category is closely related to the sustainability issues of the pension system in countries.

The remainder of the paper is organised as follows. Section 1 discusses the main relations between debt and expenditure as well as the main determinants of social expenditure and public expenditure. Section 2 discusses our model and data sets. Section 3 contains our main empirical results. Section 4 discusses the results in the context of population development in Slovakia and the Czech Republic. Consequently, Section 6 concludes.

\section{Literature Review}

Economic theory says that economic policy instruments are used to achieve sustainable economic growth in the long term. Forecast of the future economic development would be prepared much easier if economic growth was constant. However, the reality does not correspond to the theory. Achieving sustainable economic growth is closely linked to the longterm sustainability of public finances in an economy (Gavurová, 2012). Sustainability of public finances in the context of public debt and deepening the indebtedness of all market actors can be viewed from many angles. As Mirdala (2014) mentioned, significant reduction in primary budget deficit (aiming to primary surplus during a reasonable period) is the only way to reduce a negative impact of sovereign debt on economic growth.

Absorbing conclusion about the relationship between debt, investment, and productivity growth can be found in the study of Salotti and Trecrocia (2016). The authors proved that high debt levels are indeed associated with significant and sizeable declines in both private expenditure on investment and productivity growth. Particularly, they estimated the elasticity of investment to the debt/GDP level to be up to 0.10 for levels of debt equal to the advanced countries' sample average of $54 \%$ (therefore, accordingly higher when the debt/ GDP ratio assumes higher values, as in most developed countries nowadays), while a $30 \%$ difference in the debt/GDP levels can explain about $0.30 / 0.35 \%$ lower annual productivity growth. According to their words, both effects are not only highly statistically significant but also economically important. Also, Neaime (2015) clarified the sustainability of public finances through the analysis of government budgets and public debt levels.

The main emphasis is on the expenditure side of public finance. Public expenditure has gained further importance in the context of recent social developments in Europe. In particular, expenditure directed to social sphere is under the scrutiny of society. Negative demographic trends coupled with a strong wave of immigrants arriving in Europe raises questions about the sustainability of public finances combined with growing indebtedness of economies and other consequences of the economic crisis. Chang et al. (2016) argue that a higher social expenditure is usually connected with a higher government debt as higher debts reduce social expenditure. However, a speculation that higher government debt may contribute to higher social expenditure is reasonable as fiscal deficits are typical for a recession, which commonly creates greater demand for social expenditure. The authors analyse 13 OECD countries, and their conclusions suggest that higher social expenditure increases government debt. However, the shocks from government debts to social expenditure are uncertain. The authors discovered that higher government debt does reduce social expenditure. However, it may be connected to higher social expenditure. Also, the study of Yu, Fana and Magalhaes (2015) deals with the question of the public expenditure increases in the social sphere. The authors conducted the analysis on a sample of 147 countries during the period from 1980 to 2010. Total public expenditure increased significantly in selected countries as a whole. Particularly, developed countries had accounted for the majority of the absolute size of expenditure. However, some regions in developing countries, especially in Asia, had experienced a rapid expansion mainly due to strong economic growth. Also, both developing 
and developed countries had shown significant growth of social protection expenditure even though the growth in developed countries was much more pronounced. The level and the composition of total public expenditure in the social sector and social protection diverged across the regions over the period of 19802010. The particular importance of the impact of expenditure in the social area is the subject of many discussions. This area of interest has been mainly analysed in the context of population aging and long-term sustainability of public finance in Europe. However, the strong migration spread in Europe within last year has led to the consideration of public expenditure in the social area as the one of the leading criteria for considering the application for asylum of new immigrants. It is expected that this trend would continue for several years. As a result, it would create new pressure on public expenditure, especially in the social sphere. Jaime-Castillo, Marques-Perales, \& Alvarez-Galvez (2016) argue that the effect of socioeconomic status on attitudes toward immigration is larger in countries characterised by high social expenditure. However, the authors add that there is much variation between analysed countries. They state that there is the problem of the long-term sustainability of public finances in the context of the sustainability of the social system, respectively the issue of setting up and maintain the country's pension system in case of entering an increasing number of people. Many EU countries, especially in the eastern part of the Europe, have struggled with a high share of expenditure on pensions. Despite the effort of mitigating the impact of the expenditure to total public expenditure, there are still many countries exceeding the "marginal" value. The previous is also supported by the study of the World Bank (WB, 2012). This development is characteristic for all EU countries without exception. Countries such as Slovakia and the Czech Republic due to their size and age structure of the population are among the riskiest countries of the $\mathrm{EU}$ in this area (Modrakova, Hetes, \& Soltes 2013). Rievajová and Chinoracká (2013) argue that expenditure on pensions would continue to increase in both countries, i.e. in Slovakia and in the Czech Republic too. Therefore, it is necessary to take account this unfavourable demographic development related to the sustainability of the current pension systems and their correct setting. The previous considers next generations as we do not want to increase public debt related to pensions. Moreover, the authors argue that despite several ongoing demographic processes with time shifting towards the most advanced economies, the situation starts to be similar in Slovakia. Growing post-productive population means that it is inevitable to consider its increasing impact on social processes and its needs and interests. These ideas are supported in the Europe 2020, i.e. Europe's growth strategy, as the main aim of the long-term sustainability of public debt and the security of reliable and adequate pension systems was defined. The pension systems above would enable people to maintain their standard of living after the retirement. Nowadays, it is really difficult to find an optimal design of the pension system in the European countries that would guarantee a decent standard of living after the retirement and be sustainable in the long-term too. Also, it is important to realise that the examination of the demographic composition of the population is represented by the complex and long-term process. Today's generation of young people in the case of insufficient representation would cause the problems due to a lack of productive population in the long term. Therefore, the indicators of pre-productive population, postproductive population, and others, were introduced to solve the demographic problems above. The indicators are the subject of many empirical studies, e.g. the studies from the Czech Republic by Pavlík et al. (2002) or Vohralíková and Rabušic (2004). The study of Vohralíková and Rabušic (2004) introduced the Index of the economic burden that represents a number of people aged to 19 and a number of pensioners per 100 people in the productive age (20-64 years). Although the indicator declined due to decreased number of children between 2000 and 2010 from 59.3 to 54.6 , the burden of the productive population would begin to grow. Particularly, trends in the main age groups are in favour of the previous prediction. Also, the Index of the economic burden should be almost doubled in 2055 compared to the current value. As a result, from the economic point of view, the crucial would not be only the increase in the index value but also the change in the structure of dependent people as a significantly higher share in the indicator would be represented by post-productive population. Regarding the 
previous, social expenditure per person in the post-productive age would be higher than for children under 15.

In addition, there are various empirical studies in Slovakia too. For instance, the INFOSTAT (2002) in the document of "Prognóza vývoja obyvatel'stva SR do roku 2050" introduces in addition to various demographic indicators the calculation of the population development in SR till 2050 as well.

\section{Methodology and Data}

Generally, theory uses for the analysis of the impact of one or multiple variables on an observed phenomenon dynamic and stochastic regression models as well. The aim of our model is to test the hypothesis that public expenditure has a more significant influence on public debt than other selected variables. Regarding our analysis, we created a model with seven macroeconomic variables for both countries the Czech Republic and Slovakia during the period 1993-2015 on a yearly basis. Although the analysed period represents 22 years, we are aware that the analysis is based on short time series. However, it is impossible to conduct the analysis on a yearly basis using a longer period as the Czech Republic and Slovakia were once part of the one state before 1993. Statistical and econometric computations were performed in EViews statistical software. All tests conducted are based on the level of significance $\alpha=0.05$. For our analysis, we draw the data from datasets of Eurostat, AMECO, OECD, national statistical offices websites and national central banks of the Czech Republic and Slovakia. The article contains only some of the calculations; more detailed results can be requested by authors.

While choosing variables in the model, we relied on the analysis of Peková (2008) and Medved' (2005), who considered variables significantly affecting a debt such as the size of the public budget deficit, mainly government budget, inflation, the rate of economic growth, FDI and interest rate. The relationship between the debt and the interest rate is also analysed by Ardagna et al. (2007). Discussion on the relationship between debt, interest rates and economic output can be found in Baxter and King (1993). The relationship between debt and deficit can also be found in Elmendorf and Mankiw (1999); Auerbach and Gale (2009).
The response variable in our model is public debt (Debt), and explanatory variables are as follows:

- Total public expenditure - sum of all public expenditure (TExp, Million Euro);

- Gross Domestic Product (GDP, Million Euro);

- Inflation (P, \%);

- Interest rate - base interest rate PRIBOR/ BRIBOR/EURIBOR (IR, \%);

- Deficit (Def, Million Euro);

- Foreign direct investment (FDI, Million Euro).

In the first step, we applied the Augmented Dickey-Fuller test (ADF) for testing unit root, i.e. a stationarity test. Based on the results of ADF test, we can confirm that all data are stationary on the level of the first differences (see Tab. 1). Regarding the Czech Republic, data of interest rate was non-stationary, i.e., we could not reject the $\mathrm{H}_{0}$ hypothesis $\left(\mathrm{H}_{0}\right.$ : The variable has a unit root), and thus we excluded the variable. In the case of Slovakia, all variables were stationary, and thus they remained in the model. Next computations are based on the first difference of the variables.

We created a model with all selected variables. In order to estimate all beta parameters in selected equations, we employ the Ordinary Least Square (OLS) method. In addition, we conduct the hypotheses testing for parameters of the linear model along with the test of statistical significance for the parameters mentioned. Subsequently, T-statistics values and $p$-values were assessed. We set a confidence interval for beta parameters with the given number of degrees of freedom. Also, we test the model as a whole.

Both models were gradually tested for normal distribution of residuals, heteroscedasticity, autocorrelation, multicollinearity and a model specification was conducted as well (Bartóková \& Duučová, 2015). Regarding testing for normal distribution of residuals, the Jarque-Bera test was applied. According to the test, if a level of significance is less than probability value, we cannot reject the $\mathrm{H}_{0}$ hypothesis and thus variable follows a normal distribution. For that reason, we suggest that all variables tested follow a normal distribution based on the JarqueBera test. Subsequently, the Breusch-Pagan test was employed for testing the presence of heteroscedasticity. T-statistic was higher 
the Czech Republic

\begin{tabular}{l|c|l|c|l|c}
\hline \multicolumn{7}{c}{ Augmented Dickey-Fuller test } \\
\multicolumn{1}{c|}{ Factor } & t-stat (prob.) & \multicolumn{1}{|c}{ Factor } & t-stat (prob.) & \multicolumn{1}{c}{ Factor } & t-stat (prob.) \\
\hline \multirow{2}{*}{ Critical value } & $\begin{array}{c}-3.012363 \\
(0.05)\end{array}$ & \multirow{2}{*}{ dGDP } & $\begin{array}{c}-4.234303 \\
(0.0038)\end{array}$ & $\begin{array}{l}\text { dPublic } \\
\text { Expenditures }\end{array}$ & $\begin{array}{c}-3.285059 \\
(0.0289)\end{array}$ \\
\hline \multirow{2}{*}{ dDebt } & $\begin{array}{c}-3.787330 \\
(0.01)\end{array}$ & \multirow{2}{*}{ dFDI } & $\begin{array}{c}-5.112394 \\
(0.0005)\end{array}$ & dlnterest Rate & $\begin{array}{c}-2.793392 \\
(0.0779)\end{array}$ \\
\hline \multirow{2}{*}{ dDeficit } & -5.284124 & \multirow{2}{*}{ dInflation } & $\begin{array}{c}-6.666086 \\
(0.0000)\end{array}$ & & \\
& $(0.0004)$ & & & & \\
\hline
\end{tabular}

Slovakia

\begin{tabular}{|c|c|c|c|c|c|}
\hline \multicolumn{6}{|c|}{ Augmented Dickey-Fuller test } \\
\hline Factor & t-stat (prob.) & Factor & t-stat (prob.) & Factor & t-stat (prob.) \\
\hline Critical value & $\begin{array}{c}-3.012363 \\
(0.05)\end{array}$ & dGDP & $\begin{array}{c}-3.106423 \\
(0.0415) \\
\end{array}$ & $\begin{array}{l}\text { dPublic } \\
\text { Expenditures }\end{array}$ & $\begin{array}{c}-3.025891 \\
(0.0447) \\
\end{array}$ \\
\hline dDebt & $\begin{array}{c}-3.042857 \\
(0.0407)\end{array}$ & dFDI & $\begin{array}{c}-3.246557 \\
(0.0313)\end{array}$ & dlnterest Rate & $\begin{array}{c}-3.670232 \\
(0.0140)\end{array}$ \\
\hline dDeficit & $\begin{array}{c}-4.836843 \\
(0.0010)\end{array}$ & dlnflation & $\begin{array}{c}-4.749682 \\
(0.0013)\end{array}$ & & \\
\hline
\end{tabular}

Source: own calculations, results were calculated in program Eviews

than a level of significance in both countries, and thus, the $\mathrm{HO}$ hypothesis could not be rejected. Therefore, we argue that there is no heteroscedasticity. A presence of autocorrelation was based on the findings of Durbin-Watson test. We argue that there is no autocorrelation as our assumption is based on the movement of statistic value around two, respectively in the interval 1.5 to 2.5. Moreover, multicollinearity was examined by introducing the variance inflation factor (vif). Based on the vif test we argue that there is multicollinearity in some variables as the statistic value is greater than five in both models. The Ramsey reset test was used to assess the model specification. According to the results of Ramsey rest test, the model needed to be adjusted for removing some variables. Therefore, the variables of inflation and deficit in the case of the Czech Republic were excluded from the model. Similarly, the variables of inflation, interest rate, and FDI were excluded in the case of Slovakia.

Following the results before, new models for Czech Republic and Slovakia were derived as follows:

$\operatorname{Debt}_{s R}(y)=-661.969+3.747891^{*} d \operatorname{Exp}-$ $-0.844727^{*} d G D P+3.233244^{\star} d D e f$
$\operatorname{Debt}_{\check{C} R}(y)=-1286.339+0.849618^{*} d \operatorname{Exp}+$

$+0.682717^{\star} d F D I-0.406103^{*} d G D P$

Subsequently, new models were analysed by performing all five basic tests mentioned above. The model satisfied the requirements of basic tests in both countries, and thus, we argue that the model and variables are statistically significant. (Tab. 2 shows the values of t-statistic and $p$-value for statistically significant variables). Through the created linear regression functions we can explain the variability of the variable public debt at $93.9 \%$ for Slovakia and at $98.2 \%$ for the Czech Republic.

Regarding the Slovak Republic, there is a strong direct linear correlation between public debt and public expenditure. The weaker correlation is associated with the debt and deficit and the weakest with GDP. Public expenditure is the most significant variable among the considered variables. In the case of the Czech Republic, the situation is the same, i.e. the most significant variable is public expenditure concerning statistical significance. 
Tab. 2: The value of t-statistic and $p$-value for statistically significant variables

\begin{tabular}{|c|c|c|c|c|c|}
\hline \multicolumn{6}{|c|}{ the Czech Republic } \\
\hline Factor & t-stat (prob.) & Factor & t-stat (prob.) & Factor & t-stat (prob.) \\
\hline $\begin{array}{l}\text { dSocial } \\
\text { Expenditure }\end{array}$ & $\begin{array}{c}4.942977 \\
(0.0017)\end{array}$ & dFDI & $\begin{array}{c}3.674775 \\
(0.0001)\end{array}$ & dGDP & $\begin{array}{c}-3.711625 \\
(0.0034)\end{array}$ \\
\hline \multicolumn{6}{|c|}{ Slovak Republic } \\
\hline Factor & t-stat (prob.) & Factor & t-stat (prob.) & Factor & t-stat (prob.) \\
\hline $\begin{array}{l}\text { dPublic } \\
\text { Expenditure }\end{array}$ & $\begin{array}{c}6.266792 \\
(0.0000)\end{array}$ & dDef & $\begin{array}{c}-4.065973 \\
(0.0007)\end{array}$ & dGDP & $\begin{array}{c}-3.711625 \\
(0.0016)\end{array}$ \\
\hline
\end{tabular}

Source: own calculations, results were calculated in program Eviews

\section{Model Description and Results 3.1 The Czech Republic}

We use predominantly economic factors for testing the hypothesis, and thus, we examine the hypothesis that public expenditure has an impact on public debt in the Czech Republic. Also, we assume that the changes in total public expenditure, deficit, inflation, interest rate, FDI, and GDP would be statistically significant. The previous assumption was confirmed by testing the initial econometric model just for five variables (the model with six variables - see Methodology). Therefore, all three variables, i.e. total public expenditure, GDP, and FDI are statistically significant variables in connection with the change of public debt in the Czech Republic.

Particularly, we observe a rapidly increasing trend in the development of GDP mainly during the period 2000-2008. Indeed, the increasing trend is a direct result of several factors. One of the factors is an attempt to join the EU (the period 2002-2004) as a prudent fiscal and monetary policy enabled to improve the economic performance and increase the output to the level of potential output. On the other hand, rapid growth in GDP resulted in a longterm increase in public expenditure, especially in the period after joining the EU (Mura et al., 2014). The emergence of the economic crisis in 2008 contributed to a more significant decrease in GDP. However, public expenditure remained approximately at the same level (Fig. 1). The decline in GDP was stopped due to the introduced restrictive measures and thus the indicator experienced a slight increase comparing to the slower increase in public expenditure. Despite the increasing trend in GDP till 2011, the GDP rate has experienced slight decrease until now. Compared to GDP,

\section{Fig. 1: Public Expenditure and Debt - volume and ratio to GDP in period 1993-2015, the Czech Republic}

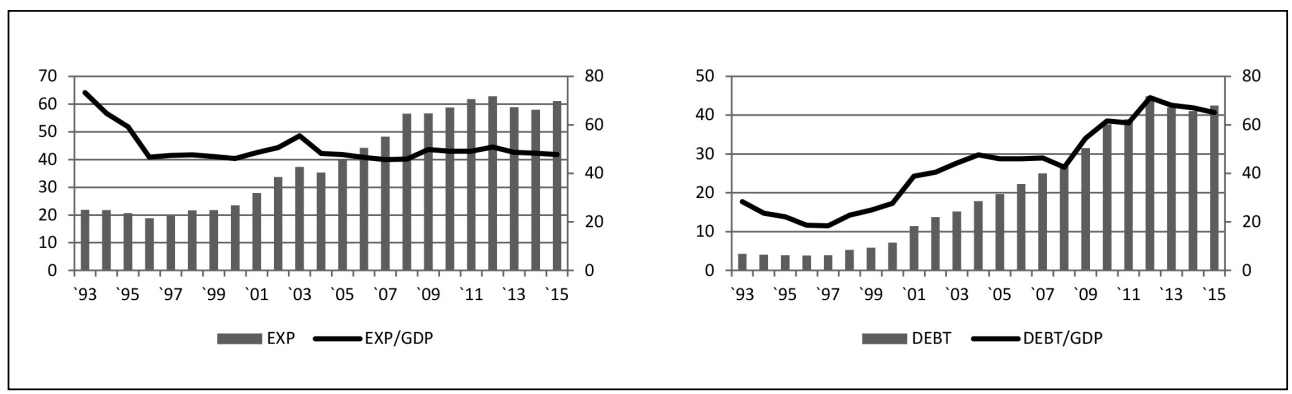

Note: left axis is \%, right axis is billion Euro 


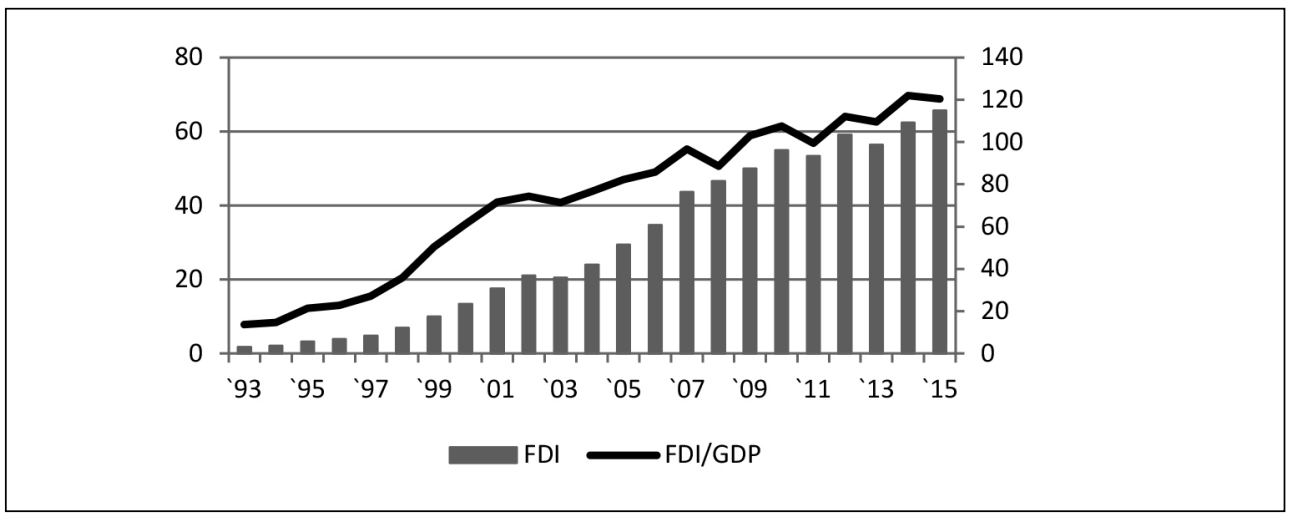

Note: left axis is \%, right axis is billion Euro

public expenditure has remained at the same level. Although the total growth of total expenditure was not significant, it moved in a regular way. The total value of public expenditure has increased three times during the analysed period (since 1999).

The FDI increased throughout the reporting period in volume and as a proportion of GDP too. The ratio to GDP increased to seven times during 22 years. The fastest growth in FDI was shown in years 2004-2008, i.e. the period of economic growth of the country (Fig. 2).

The result of the basic empirical model confirms our initial hypothesis. For that reason, we focus on the most significant variable and examine the composition of total public expenditure. Our findings suggest that total public expenditure represents a sum of the values in ten categories of public expenditure into different areas of an economy. As a result, the biggest part of total value is represented by one category of expenditure, social expenditure
(SocExp), that appear to have a $30 \%$ share of total public expenditure. Based on the previous fact, we re-examined the hypothesis. The result of the model is described as follows:

$$
\begin{aligned}
& d \operatorname{Debt}_{C R}\left(y_{C R}\right)=5891.529 .11+ \\
& +2.937082^{*} d S o c E x p- \\
& -0.431412^{*} d G D P+0.692786 d P Z I
\end{aligned}
$$

Finally, our hypothesis is confirmed. Social expenditure represents the most significant variable as it has the strongest correlation with the change of public debt. Strikingly, a change in a unit of social expenditure would result in about 3-times stronger change in public debt.

\subsection{Slovakia}

Similarly, we use the same economic factors as above for testing the hypothesis. We assume that the similarity of countries would reflect in that case too. However, the results of the

The value of t-statistic and p-value for statistically significant variables - model with social expenditure

\begin{tabular}{l|c|l|c|l|c}
\multicolumn{1}{c}{ the Czech Republic } \\
\hline \multicolumn{1}{c|}{ Factor } & t-stat (prob.) & Factor & t-stat (prob.) & Factor & t-stat (prob.) \\
\hline dSocial & 4.080517 & \multirow{2}{*}{ dFDI } & $\begin{array}{c}2.852500 \\
(0.0106)\end{array}$ & dGDP & 2.209965 \\
Expenditure & $(0.0007)$ & & & $(0.0403)$ \\
\hline
\end{tabular}


test confirm that the variables of the deficit, public expenditure, and GDP are significant for the model. Therefore, changes in public expenditure or deficit as well result in an approximately equally change in public debt. The coefficients of these variables are roughly equal, i.e., the coefficient for public expenditure is 3.747 and for deficit represents the value of 3.233. The change in GDP in comparison to the previous change results in a much smaller effect that is expressed by the coefficient equal to -0.844 .

\section{Fig. 3: Deficit and Debt - volume and ratio to GDP in period 1993-2015, Slovakia}

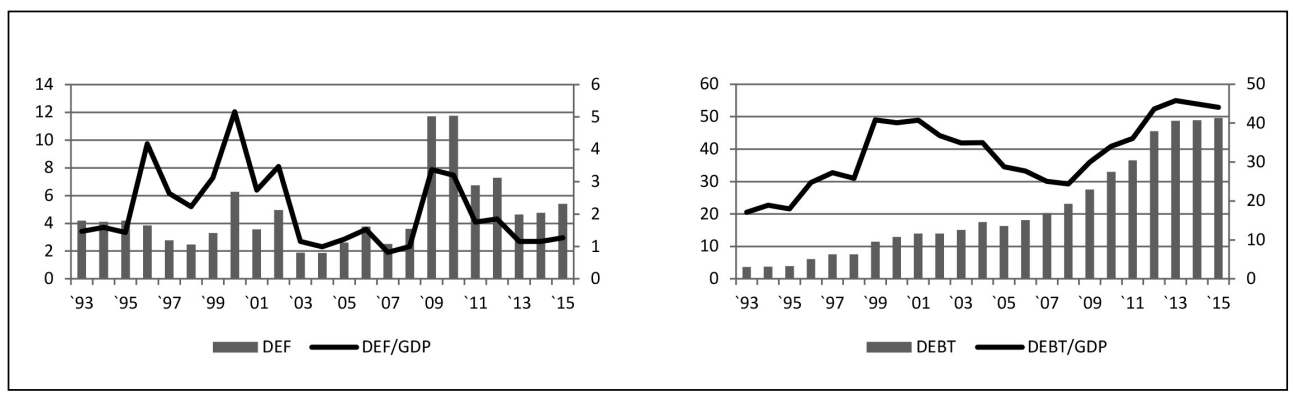

Note: left axis is \%, right axis is billion Euro

\section{Fig. 4: Public Expenditure - volume and ratio to GDP in period 1993-2015, Slovakia}

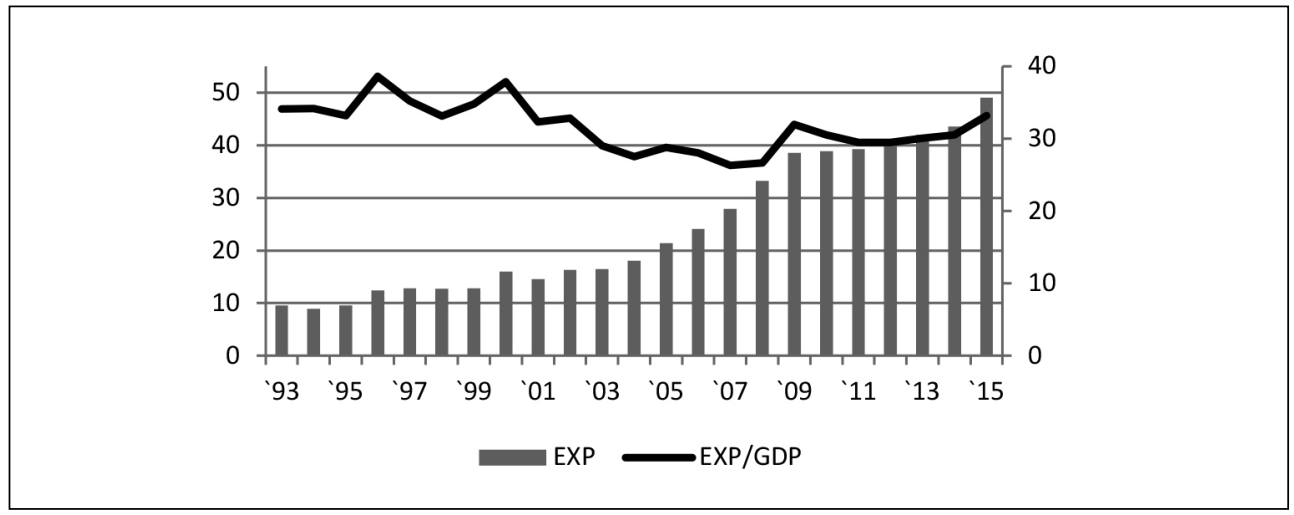

Note: left axis is \%, right axis is billion Euro

The development of the variables of public debt, deficit, and public expenditure show common features. Fig. 3 indicates that the government tried to mitigate the level of deficit to GDP predominantly in the period 2004-2007, i.e. the period of economic growth. However, we can distinguish two periods that are characterised by an increasing deficit. The previous corresponds to the period of consolidation between the years 1998-2001 and the period of the crisis in 2008-2010. Furthermore, the development of public debt to GDP followed the development of deficit to GDP mainly in the period of consolidation 
(1996-2000) and the crisis period while the ratio of public debt to GDP increased. Also, we can observe the development of public debt to GDP in the period of economic growth, i.e. the period 2004-2007 where the GDP growth was faster that the growth of public debt. Also, the positive fact is that the ratio of deficit to GDP in 2015 is on the lower level than in 1993. Consequently, the ratio of public debt to GDP has increased from $20 \%$ of GDP in 1993 to $55 \%$ of GDP in 2015. The public expenditure has shown an increase during the analysed period as well.

Fig. 4 shows that the value has reached on average $42 \%$ of GDP. Moreover, the economic performance of Slovakia has not required any additional excessive public expenditure in the pre-crisis period. Generally, we have observed the improvement in the economic performance since the joining the EU and the introduction of structural reforms. Moreover, structural reforms accompanied by restrictive fiscal policy and early attempts at adopting the euro as a domestic currency resulted in $10.4 \%$ growth of GDP in 2007. Also, a deficit in public finance has experienced a positive development as mentioned above. Particularly, increased revenues due to a new tax reform have enabled to finance increased public expenditure (Andrejovská \& Mihoková, 2015).

The breakthrough was the year 2008 as Slovakia battled against the economic crisis. Subsequently, GDP and deficit had a positive development as the variables approached the pre-crisis values within the following five years. However, GDP returned to slow growth after a slight increase in 2009 and 2010. The major problem remained a continual increase in public expenditure. Although its growth rate was not so fast as in the period between 2004-2010, it has been gradually approached it.

The result of the basic empirical model confirms our initial hypothesis, similarly as in the case of the Czech Republic. We follow the same approach as above and examine the composition of total public expenditure. Following our results, we select the category with the highest ratio to total public expenditure. The final sum of the variable above represents $16 \%$ of total public expenditure. Strikingly, social expenditure in the Czech Republic represents approximately $30 \%$ of total public expenditure. Our procedure was similar to the one of the Czech Republic, i.e. we applied new category into the model. Moreover, we used the test of stability, and there we discovered a problem. There was no reason to reject the null hypothesis about the unit root (t-statistics $=-2.05897$, critical value $=-3.012363$ ). For that reason, we excluded this factor from the model. Subsequently, it was not possible to verify the null hypothesis.

\section{Discussion of Results}

Despite the fact that we were unable to confirm the hypothesis concerning social expenditure in the case of Slovakia, we decided to compare the results from the considered field of study for both countries.

The results point out to the fact that the most significant component of social expenditure in both analysed countries is the old age expenditure (the represented share in the case of Slovakia is $47 \%$ and in the Czech Republic $59 \%$ of social expenditure). Also, the other important components are sickness and disability $(44 \%$ in Slovakia and $22 \%$ in the Czech Republic of social expenditure). The methodology of Eurostat in the case of old age expenditure includes mainly old age pensions in an economy and the provision of goods and services to the elderly as well. Similarly, the variables of sickness and disability include paid sick leave, medical care and the provision of pharmaceutical products, disability pensions and the provision of goods and services to the disabled. (EUROSTAT, 2016a) Regarding the previous findings, it is crucial to solving the issue of public finance setting and its further sustainability. The solutions should be based on the correct perception in the case of population aging in Europe. Growing number of the postproductive population will lead to an increase in two variables mentioned and thus to a further increase due to their impact on public debt. However, the positive development of the preproductive age and the post-productive age population to the pre-productive population could help the situation.

The Fig. 5 (left) shows the current situation in Slovakia. We argue that the share of the young population (the population aged 0-16) in the total population has been permanently decreased during the examined period. This fact is also mentioned in the document INFOSTAT (2002) as a decrease in population growth will be the main feature of demographic development in Slovakia in the following 50 years. The intensity of the process above will 
directly depend on the assumptions of future trends in fertility and migration. Moreover, it will be indirectly dependent on demographic, social, political, economic, cultural and other factors. (INFOSTAT, 2002) In comparison with Slovakia, the Czech Republic has experienced a significant decrease in the analysed indicator (Fig. 5 - right). The previous corresponds to the conclusions about the negative development in the demographic curve regarding all EU countries (see EC (2012b)). Based on the analysed data, the movement of the category considered to positive directions has been changed slightly since 2012. However, the previous is in contrast with the prognoses of the Czech statistical office (CZSO, 2012) regarding the further development. According to the CZSO (2012), younger age groups grow relatively slower than the total population predominantly due to the decline in fertility (as a result of economic, health or social problems).

\section{Fig. 5: The Development of Population Ratios in Period 1999-2014, (\%)}

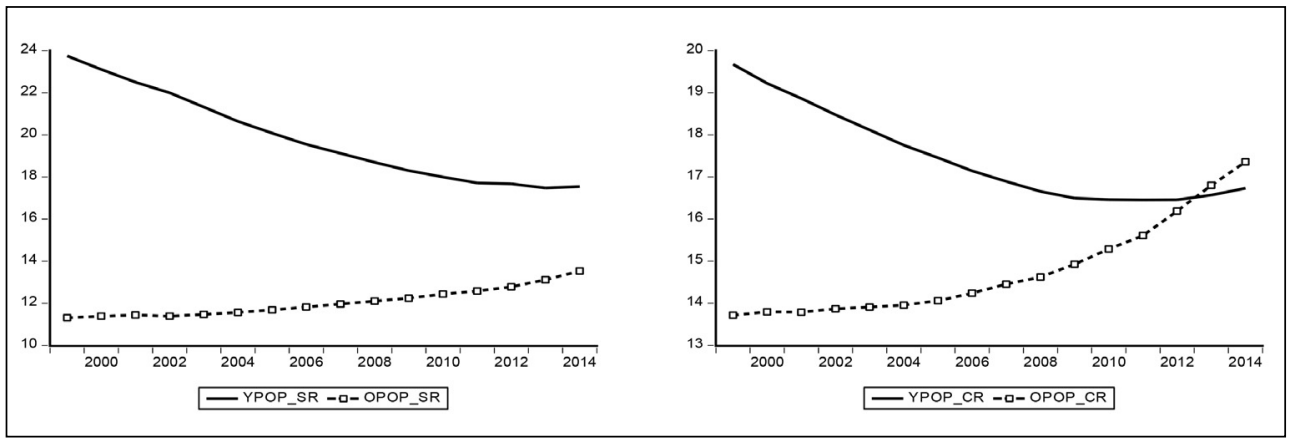

Note: YPOP - a ratio of the population aged less than 16 to the total population (\%), OPOP - a ratio of the population aged 65 and over to the total population (\%)

Strikingly, the post-productive population has experienced quite a different development during the analysed period (Fig. 5). The share of the post-productive population in the total population have permanently increased in both countries since 1999. Slovakia has experienced the slow increase in the value of the indicator while the Czech Republic have shown a significant permanent growth rate since 2005. In fact, the share of the post-productive population in the total population overrun the share of the young population in the total population in 2012. The previous development is expected to happen in the following ten years in the case of Slovakia. A similar expression can be found in Cecchetti, Mohanty and Zampolli (2011), who state: Unfortunately, the unprecedented acceleration of population aging that many industrial countries now face may make this task even more difficult. First, aging drives government revenue expenditure up and down, worsening debt directly. But, as our results in the previous section suggest, there is an additional effect: Rising dependency ratios put further downward pressure on the trend growth, over and above the negative effects of debt. According to INFOSTAT (2002) the population aging in Slovakia is going to accelerate in the next decades. This is an irreversible process that could only be mitigated. The CZSO (2012) and INFOSTAT (2002) agree that the reason for a significant increase in a share of the post-productive population is the improvement in the mortality ratios, especially in the old age population. The estimations of the CZSO (2012) are based on the hypothesis that a number of people over 80 is going to increase 4 times in the following five years. The previous fact corresponds to the post-productive population aging. Moreover, the CZSO (2012) stresses another important economic issue as the increase in the population over 80 is going to lead simultaneously to the increase in the health care and social expenditure for this 
population (CZSO, 2012). Goliaš (2010) tried to analyse the possible solutions to this problem too.

Also, the current level of health care is one of the main factors of the development considered. Particularly, the progress in health care during the previous decades have even enabled to prolong the life of the people that would not survive without medicine. According the study of European Commission "Public Finance Sustainability", the higher expectations are not considered to be the only problem. Indeed, the period of receiving the pensions that takes into account life expectancy is supposed to be a serious economic issue. In order to find a suitable solution, we would have to set a mechanism for calculating a retirement age. According to the forecasts found in the study of Rievajová and Chinoracká (2013), the public expenditure on pensions is going to increase by $5.2 \%$ in Slovakia and by $2.7 \%$ in the case of the Czech Republic in the following 50 years.
Furthermore, the indicator "S2" is in favour of linking the demographic development with the fiscal position of a country. The indicator provides quantification of the current structural primary balance ( $\%$ of GDP) in the way that the current value of future structural primary balances would cover public debt level. (EC, $2012 b)$ Based on the indicator, the change in the Czech Republic corresponds to $5.5 \%$ of GDP and in Slovakia $6.9 \%$. This indicates that the population aging is not the only problem in the area of public finance but even the total value of public expenditure and the fiscal policy setting in a country too. For that reason, we present our short-term estimation of public debt development based on our econometric model. The estimation is affected by social expenditure development and GDP in the case of the Czech Republic and the estimated deficit development in the case of Slovakia besides mentioned too (Fig. 6).

\section{Fig. 6: The Forecast of the Future Debt and Public Expenditure Development (period 2015-2017, Million Euro)}

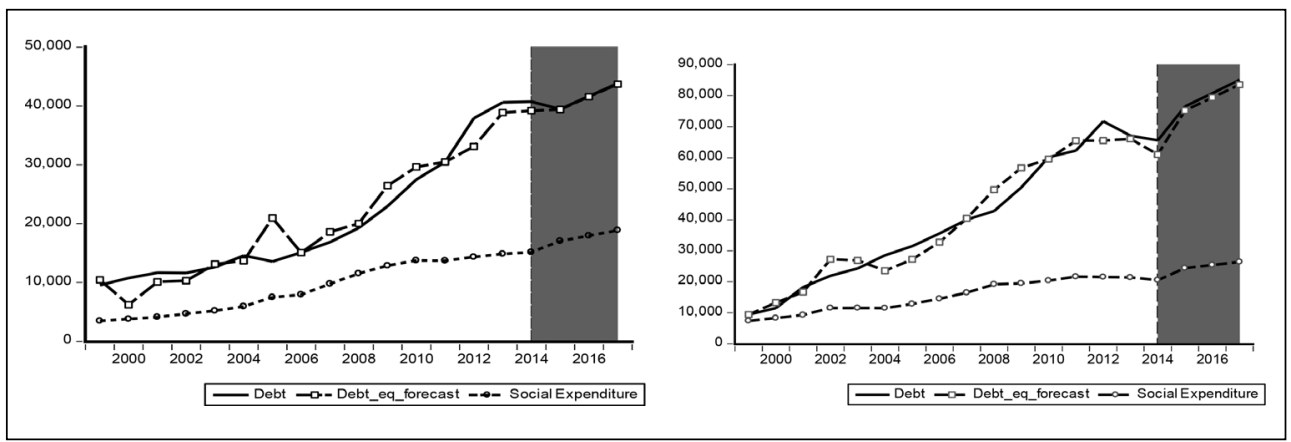

Note: left SR, right CR

Following the development shown in the figures, we assume that the debt is going to increase in both countries. Also, we argue that an increase in social expenditure has the potential to be a significant factor regarding an increase in debt. Although we cannot prove the previous based on our results (and also it was not the aim of our paper), we assume that it is necessary to find the complex solution for stabilisation policy, not only for one part of it. The previous is supported by the studies mentioned above. Moreover, the previous raises the question how much attention has been paid to the analysis of the fiscal policy setting and the provision and administration of social expenditure as the part significantly contributing to higher public debt.

\section{Conclusions}

The topic of the massive international indebtedness is a subject of many academic discussions in the recent period. Our study has followed and analysed the approach that public expenditure, especially social expenditure is 
considered to be a factor with significant power to contribute to increased indebtedness. The primary hypothesis that the variable of public expenditure is more significantly correlated with the changes in public debt than other analysed variable was confirmed. Moreover, the result was the same in both analysed countries. On the other hand, our second hypothesis that the variable of social expenditure is more significantly correlated with the changes in public debt than other analysed variables was confirmed only for the Czech Republic. The character of the values did not allow us to find the answer. Following our results, we argue that social expenditure can be considered as the potential variable having the negative impact on debt, i.e. it contributes to higher debts in the Czech Republic. The category of pensions and health care expenditure is considered to be the one of the most problematic areas of interest (widely associated with increasing life expectancy). As a result, the pressure for a further increase in public expenditure, especially social expenditure is created as it requires the health care financing mentioned with longer periods of pensions. Therefore, the intensity of the expenditure above will gradually raise the debt level (ceteris paribus). Avoiding or postponing the solutions of this problem would harm efficiency of the economic policy setting and would lead to long-term instability in an economy. In this context, the paradox is created that is difficult to deal with it. The question of further medical progress is in contrast to the question of financing the population aging (pensions, health care). In particular, when the success in the medicinal field leads to the pressure on public expenditure regarding the long-term sustainability and effectiveness, we face a dilemma as the question of ethics, morality and humanity is against the economic functioning of the society as a whole.

This paper was written in connection with scientific project VEGA no. 1/0994/15. Financial support from this Ministry of Education's scheme is also gratefully acknowledged.

We thank to anonymous reviewers of the E\&M Economics and Management for their very useful comments.

\section{References}

AMECO. (2016). General government. Retrieved April 25, 2016, from http://ec.europa. eu/economy_finance/db_indicators/ameco/ index_en.htm.

Andrejovská, A., \& Mihóková, L. (2015). Developments of VAT rates in EU countries in the context of harmonization and fiscal consolidation. Acta universitatis agriculturae et silviculturae Mendelianae brunensis, 63(2), 487-498. doi:10.11118/actaun201563020487.

Ardagna, S., Caselli, F., \& Lane, T. (2007). Fiscal discipline and the cost of public debt service: some estimates for OECD countries. B. E. Journal of Macroeconomics, 7(1), art. 28.

Auerbach, A. J., \& Gale, W. G. (2009). Activist fiscal policy to stabilize economic activity. Mimeo.

Bartóková, L'., \& Ďurčová, J., (2015). Effectiveness of the monetary policy implementation in the context of crisis: use of the short-term interest rate in the Czech Republic and the EMU. E\&M Ekonomie a Management, 18(1), 4-17. doi:10.15240/tul/001/2015-1-001.

Baxter, M., \& King, R. G. (1993). Fiscal policy in general equilibrium. American Economic Review, 83(3), 315-334.

Chang, C. P. et al. (2016). Does higher government debt link to higher social expenditure? New method, new evidence. Applied Economics. 48(16), 1429-1451. doi:10. 1080/00036846.2015.1044745.

Cecchetti, S. G., Mohanty, M. S., \& Zampolli, F. (2011). Achieving Growth Amid Fiscal Imbalances: The Real Effects of Debt. In Economic Symposium Conference Proceedings (pp. 145-196). Jackson Hole: Federal Reserve Bank of Kansas City.

CNB. (2016). Central Bank Exchange Rate. Retrieved April 25, 2016, from https://www.cnb. cz/en/financial_markets/foreign_exchange_ market/exchange_rate_fixing/daily.jsp.

CZSO. (2016). Populační prognóza ČR do r.2050. Retrieved April 25, 2016, from https:// www.czso.cz/csu/czso/populacni-prognoza-crdo-r2050-n-g9kah2fe2x.

EACG. (2012). Sustainability of pension systems in Europe - the demographic challenge. Retrieved May 20, 2016, from http:// actuary.eu/documents/Sustainability_pension_ system_\%20final_020712\%20270612_web.pdf.

EC. (2012a). White paper: An agenda for adequate, safe and sustainable pensions. Retrieved May 02, 2016, from http://www.cicero- 
group.com/wp-content/uploads/2012/02/

Pensions-White-Paper-Special1.pdf.

EC. (2012b). The 2012 Ageing Report Economic and budgetary projections for the 27 EU Member States (2010-2060). European Union. doi:10.2765/19991.

Ellison, R. (2012). European pensions policy and the impact of the EU pensions directive for employers worldwide. Pensions: An International Journal, 17(4), 305-333. doi:10.1057/pm.2012.36.

Elmendorf, D. W., \& Mankiw, N. G. (1999). Government debt. In J. B. Taylor and M. Woodford (Eds.), Handbook of Macroeconomics (pp. 1615-1699). Amsterdam: Elsevier Science.

Eurostat. (2016a). Social protection statistics. Retrieved April 25, 2016. from http:// ec.europa.eu/eurostat/statistics-explained/ index.php/Social_protection_statistics.

Eurostat. (2016b). Economy and Finance. Retrieved May 9, 2016, from http://ec.europa. eu/eurostat/data/database.

Gavurová, B. (2012). Source Identification of Potential Malfunction of Balanced Scorecard System and Its Influence on System Function. E\&M Ekonomie a Management, 15(3), 76-90.

Goliaš, P. (2011). INEKO: Monitoring dlhodobej udržatel'nosti verejných financií $v S R$. Retrieved April 23, 2016, from http://www.ineko. sk/clanky/monitoring-dlhodobej-udrzatelnostiverejnych-financii-v-sr.

INFOSTAT. (2016). Prognóza vývoja obyvatel'stva SR do roku 2050. Retrieved April 22, 2016, from http://www.infostat.sk/vdc/pdf/ prognoza2050vdc2.pdf.

Jaime-Castillo, A. M., Marques-Perales, I., \& Alvarez-Galvez, J., (2016). The Impact of Social Expenditure on Attitudes Towards Immigration in Europe. Social Indicators Research, 126(3), 1089-1108. doi:10.1007/s11205-015-0939-0.

Medved', J. et al. (2005). Verejné financie. Bratislava: Sprint.

Mirdala, R. (2014). Periods of Fiscal Consolidation in Selected European Economies. In Procedia Economics and Finance: Emerging Markets Queries in Finance and Business (pp. 137-145). Elsevier. doi:10.1016/S22125671(14)00462-6.

Modráková, E., Heteš, J., \& Šoltés, M. (2013). Analysis of saving on pension. In Procedia Economics and Finance: Emerging Markets Queries in Finance and Business (pp. 1413-1419). Elsevier. doi:10.1016/S22125671(14)00606-6.
Mura, L. et al. (2014). Identification of Funding of Regional Governments Using Correlation Analysis. In Procedia Economics and Finance: Emerging Markets Queries in Finance and Business (pp. 154-161). Elsevier. doi:10.1016/S2212-5671(14)00466-3.

NBS. (2016). Central Bank Exchange Rate. Retrieved April 25, 2016, from http://www.nbs. sk/sk/statisticke-udaje/udajove-kategorie-sdds/ urokove-sadzby/urokove-sadzby-ecb.

Neaime, S. (2015). Sustainability of budget deficits and public debts in selected European Union countries. The Journal of Economic Asymmetries, 12(1), 1-21. doi:10.1016/j. jeca.2014.10.002.

OECD. (2016). Social Expenditure Table. Retrieved April 12, 2016, from https://stats. oecd.org/Index.aspx?DataSetCode=SOCX_ AGG\#.

Pavlík, Z. et al. (2002). Populační vývoj České republiky 1990-2002. Praha: KDGD PřF UK.

Peková, J. (2008). Veřejné finance - úvod do problematiky. Praha: ASPI Publishing.

Reinhart, C. M., \& Rogoff, K. S. (2009). This Time is Different: Eight Centuries of Financial Folly. Princeton, NJ: Princeton University Press.

Rievajová, E., \& Chinoracká, A. (2013). Verejné výdavky na dôchodky v krajinách EU. Acta academica karviniensia. 13(4), 163-174.

Salotti, S., \& Trecroci, C. (2016). The Impact of Government Debt, Expenditure and Taxes on Aggregate Investment and Productivity Growth. Economica, 83(330), 356-384. doi:10.1111/ ecca. 12175.

Soltes, V., \& Gavurova, B. (2014). Innovation policy as the main accelerator of increasing the competitiveness of small and medium-sized enterprises in Slovakia. In Procedia Economics and Finance: Emerging Markets Queries in Finance and Business (pp. 1478-1485). Elsevier. doi:10.1016/S2212-5671(14)00614-5.

Stuart-Hamilton, I. (1999). Psychologie stárnutí. Praha: Portál.

Vohralíková, L., \& Rabušic, L. (2004). Čeští senioři včera, dnes a zítra. Brno: VúPSV.

Yu, B. X., Fana, S. G., \& Magalhaes, E. (2015). Trends and Composition of Public Expenditures: A Global and Regional Perspective. European Journal of Development Research, 27(3), 353-370. doi:10.1057/ ejdr.2015.26. 
WB. (2015). Aging and Pension Expenditures. Retrieved April 23, 2016, from http://siteresources.worldbank.org/ ECAEXT/Resources/publications/4547631181939083693/chaw_151-176_ch04.pdf.

Ing. Manuela Raisová, PhD. Technical University of Košice

Faculty of Economics

Department of Economic Theory manuela.raisova@tuke.sk
Ing. L'udmila Pavliková, PhD. Technical University of Košice Faculty of Economics Department of Banking and Investment ludmila.pavlikova@tuke.sk

Ing. Jozefína Semančíková Technical University of Košice Faculty of Economics Department of Economic Theory jozefina.semancikova@tuke.sk 


\title{
Abstract
}

\section{THE IMPACT OF SOCIAL EXPENDITURE ON PUBLIC DEBT IN THE CZECH REPUBLIC AND SLOVAKIA}

\author{
Manuela Raisová, Ludmila Pavliková, Jozefína Semančíková
}

Europe is facing the problem of growing consumption and increasing volume of public expenditure too for years. Financing of public expenditure (as a sum of short-term, medium or long term projects) is a complicated issue. Regarding the financial perspective, the primary result is the creation of budget deficits. Countries are currently not able to deal with them, and thus this problem leads to the creation of new deficits. Therefore, an economy creates public debt - through the accumulation of deficits. The aim of our paper is to examine the effect of social expenditure on public debt. We have focused on the examination of only two countries - the Czech Republic and Slovakia. Our findings confirm that social expenditure represents a significant proportion of public expenditure. Moreover, public expenditure and social expenditure as well have increased in volume in the previous years. Governments use them to fulfil their social role in the economy. From this perspective, financing of social expenditure also contributes to the deficit, and in the long term to the creation of public debt. For that reason, another objective of our paper is to verify the effect of social expenditure on public debt. We examine the primary hypothesis on the significant correlation between public expenditure and public debt. As a result, we created an econometric model to test our hypothesis that the variable of public expenditure is more significantly correlated with public debt than other selected economic variables. Moreover, we modified the model, and we tested the hypothesis that social expenditure is more significantly correlated with public debt than other selected economic variables. We found that hypothesis concerning public expenditure had been confirmed for both countries. Hypothesis about social expenditure was confirmed for the Czech Republic. However, in the case of Slovakia, this hypothesis could not be verified.

Key Words: Public debt, population ageing, social expenditure, Slovakia, the Czech Republic.

JEL Classification: H51, H55, H62, H63, H68.

DOI: 10.15240/tul/001/2016-3-011 